
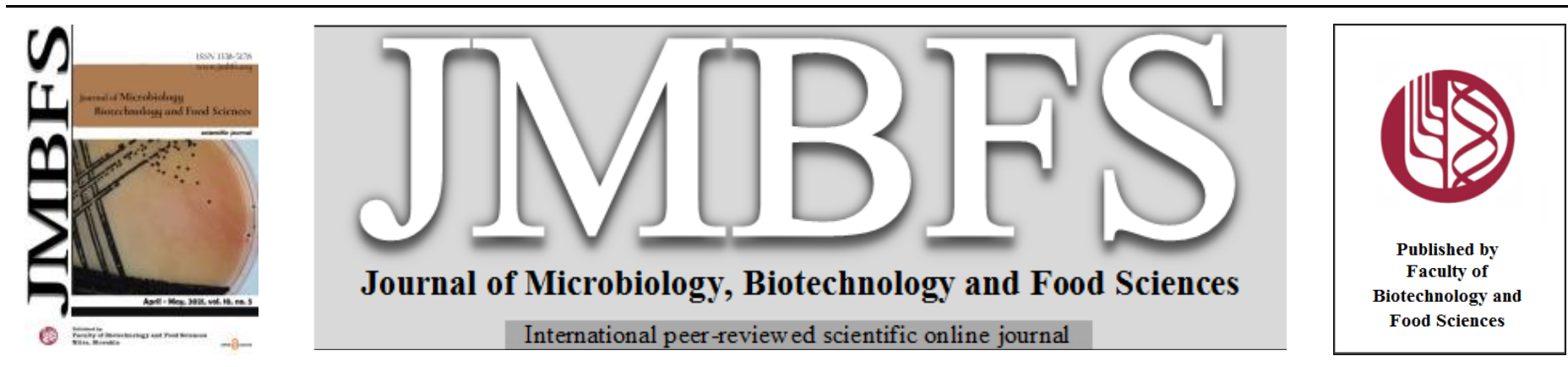

\title{
EVALUATION OF ACUTE TOXICITY EXPOSURE TO AQUEOUS LEAVES EXTRACT OF SYZYGIUM KANARENSE (TALBOT) RAIZADA
}

\section{Divakar M $S^{1,}$ Raju Krishna Chalannavar*², Souvik Debnath ${ }^{3}$, Tapan Kumar Chatterjee ${ }^{3,4}$, Sooryaprakash Shenoy $H^{5}$}

Address(es): Dr. Raju Krishna Chalannavar,

${ }^{1}$ Mangalore University, Mangalgangothri, Research scholar, Biotechnology Unit, Department of Biosciences, Konaje, Mangalore-574199, Karnataka, India. Phone number: 8792494064.

${ }^{2}$ Mangalore University, Mangalgangothri, Professor, Department of Applied Botany, Konaje, Mangalore-574199, Karnataka, India.

${ }^{3}$ Jadavpur University, Research scholar, Division of Pharmacology Research Laboratory, Department of Pharmaceutical Technology, Kolkata- 700032, West-Bengal, India.

${ }^{4}$ JIS University, Professor, Department of Pharmaceutical Science and Technology, Kolkata-700032, West-Bengal, India.

${ }^{5}$ Dr. ShivaramaKarantha Pilikula Nisargadhama, Principal Scientist \& Head of Botany Division, Moodushedde, Mangalore-575028, Karnataka, India.

*Corresponding author: drrajkc@gmail.com

https://doi.org/10.15414/jmbfs.2219

\section{ARTICLE INFO}

Received 8. 11. 2019

Revised 9. 11. 2020

Accepted 11. 11. 2020

Published 1. 4. 2021

Regular article open 2 access

\section{ABSTRACT}

Syzygium kanarense (Talbot) Raizada (Family: Myrtaceae), a rare plant tested for toxicity in order to explore therapeutic value. In the current study, the preliminary phytochemical screening, in vitro toxicity and acute toxicity of aqueous extract of Syzygium kanarense leaves (AESKL) were evaluated. Phytochemicals were screened and cytotoxicity was confirmed by MTT assay using NIH/3T3 cell line. For acute toxicity evaluation, female rats were divided into two equal groups; one group served as control while the other group received a single dose of AESKL at $2000 \mathrm{mg} / \mathrm{kg}$ body weight (b.w) were treated and observed for 14 days. AESKL contains phenolics, tannins, terpenoids, saponins and steroids. The result showed the cytotoxicity value of inhibitory concentration $\left(\mathrm{IC} \mathrm{F}_{50}\right)=491.56 \mu \mathrm{g} / \mathrm{ml}$ of AESKL. Acute toxicity of AESKL established the Lethal Dose $\left(\mathrm{LD}_{50}\right)$ more than $2000 \mathrm{mg} / \mathrm{kg}$ b.w and no mortality rate was observed. No changes in behavioural, b.w, relative organ weight, haematological, biochemical and histological were observed. Based on the results, it can be conclude that AESKL do not pose any risk when given orally to rats. To the best of our knowledge, this is the first report on evaluation of in vitro and in vivo toxicity of AESKL.

Keywords: Syzygium kanarense, Phytochemicals, Cytotoxicity, Acute toxicity

\section{INTRODUCTION}

Natural products keep on playing a highly significant role for innovative drugs in the pharmaceutical industry, (Mohanraj et al., 2018) and their derivatives have traditionally been a valuable source of active ingredients in medicines. However, new technological advances that assist address these issues, attached with unrealized expectations from current lead-generation strategies, need to show the way to an interest in natural products for drug discovery (Koehn et al., 2005). The use of natural products has increased due to the fact that the population believes that natural products do not exhibit any toxic effects (Yuan et al., 2016). It is expected that the more effective and efficient use of natural products could improve the discovery of drugs. Many historical studies confirm the early use of plants for medicinal purposes (Lietava et al., 1992). According to World Health Organization (WHO) report, $75-80 \%$ of the world's population depends primarily on plant-resource medicine (Ghosh and Rangan, 2013). In ethnomedicine, most medicinal plants play an essential role in the treatment of various ailments with lesser or no side effects. There are many benefits of using plant products for health-related issues as the organ damage recovered, the risk of death can reduce, and the frequency of health problems can also effectively reduced. The various efforts made by researchers, modern medicine, have gradually developed in recent years. However, traditional medicine remains the basis for the development of new drugs (Patwardhan et al., 2004). The increasing number of herbal drug users worldwide and the lack of historical evidence on the safety profile of herbal medicinal products make it necessary to carry out toxicity studies (Saad et al., 2006).

Western Ghats of India is a store house of many unidentified medicinal plants that are yet to be explored. The species of Syzygium is known as medicinal plants for the treatment of diabetes mellitus and various diseases. Syzygium is a genus of flowering plants under the Myrtaceae family, and the native range of distribution extends from Africa and Madagascar through Southeast Asia. It has the maximum level of diversity from Malaysia to Northeast Australia, where many species are very poorly identified and many more have not been taxonomically described (Nigam et al., 2012). Syzygium species showed the number of pharmacological actions, including anticancer and anti-diabetic activity (Chew et al., 2017). Currently, Syzygium is a tropical tree, and many reports have shown it to be a valuable therapeutic agent. Its potential, as an active anti-diabetic agent cannot be ruled out. Lack of large scale studies is seen that needs to be focused in order to explore the effective phytopharmaceutical drugs by Syzygium species; the initial data seems to be favourable. Among the species of Syzygium, one of the rare plants, S. kanarense, described by Talbot (1897) from the evergreen forests of Gerusoppa ghat was reported to be endemic in Shimoga and North Kanara districts of Karnataka, India (Ahmedullah and Nayar, 1986). However, the species was recollected in 1964 by $R$. Sundararaghavan after 67 years, but this was not reported even after depositing the species in BSI Western circle, Poona. Later on, in the year 1996, Nayar reported that $S$. kanarense was considered as a critically endangered species and last seen by Talbot discounting the collection of R. Sundararaghavan. After a long period of 47 years, this plant has been rediscovered from evergreen forests and belongs to the Myrtaceae family (Shenoy et al., 2015). Still, no data available in S. kanarense plant species. The plant family Myrtaceae is rich in volatile oils, and fruits are commonly used as traditional medicine. Joshi et al. (2017) investigated the chemical composition of the essential oil of $S$. kanarense and reported a total of 52 constituents from the aerial parts. However, there are no reports on toxicological studies of this species. Hence, an attempt was made to carry out the preliminary phytochemical screening, in vitro toxicity and oral acute toxicity of AESKL.

\section{MATERIALS AND METHODS}

Collection of plant material and preparation of crude extract

The fresh leaves of Syzygium kanarense collected during the month of September, 2018 from Pilikula Nisargadhama, Mudushedde (N 12.9299, E 74.8958), Mangalore, Dakshina Kannada district, Karnataka, India (voucher 
specimen No. PND-800, flower: 2385 and plant fruiting: 2520). To prepare the plant crude extract, around $2 \mathrm{~kg}$ of leaves were washed thoroughly under running tap water to remove dirt and rinsed in distilled water. Further, the leaves were shade-dried at room temperature for about 20 days. The dried leaves were powdered using electric grinder and stored in brown bottle until further use. About $150 \mathrm{~g}$ of dried leaf powder was extracted in distilled water $(500 \mathrm{ml})$ at room temperature using magnetic stirrer for a period 24 hours. Following this, the extract was filtered by Whatman no.1 filter paper. The liquid extract evaporated in the oven at a temperature not exceeding $60^{\circ} \mathrm{C}$. The dried extract was stored at $4^{\circ} \mathrm{C}$ in refrigerator until further use.

\section{Preliminary phytochemical screening}

\section{Test for alkaloids}

Wagner's test: A few drops of Wagner's reagent added to the crude extract along the sides of the test tube. A reddish-brown coloured precipitate indicated the presence of alkaloids (Banu and Cathrine, 2015).

\section{Test for phenolic compounds}

a) Ferric chloride test: The extract of $50 \mathrm{mg}$ dissolved in distilled water $(5 \mathrm{ml})$. Few drops of neutral 5\% ferric chloride solution added. Dark green colour indicates the presence of the phenolic compounds (Banu and Cathrine, 2015).

b) Gelatin test: $50 \mathrm{mg}$ of extract was dissolved in $5 \mathrm{ml}$ of deionised water and 2 $\mathrm{ml}$ of $1 \%$ Gelatin solution containing $10 \% \mathrm{NaCl}$ added to it. A white precipitate indicated the presence of phenolic compounds (Banu and Cathrine, 2015).

c) Lead acetate test: The extract $(50 \mathrm{mg})$ dissolved in $5 \mathrm{ml}$ distilled water and to this $3 \mathrm{ml}$ of $10 \%$ lead acetate solution. A white precipitate indicated the presence of phenolic compounds (Banu and Cathrine, 2015).

\section{Test for flavonoids}

Alkaline reagent test: Crude extract treated with $10 \% \mathrm{NaOH}$ solution; the formation of intense yellow colour indicates the presence of flavonoid (Sawant and Godghate, 2013)

\section{Test for terpenoids}

Salkowski test: Crude extract was shaken separately with chloroform $(2 \mathrm{ml})$ followed by the addition of concentrated sulphuric acid $(3 \mathrm{ml})$ along the side of the test tube, the reddish-brown colouring of the interface indicates the presence of terpenoid (Edeoga et al., 2005).

\section{Test for tannins}

Crude extract $(0.5 \mathrm{gm})$ was stirred with distilled water $(10 \mathrm{ml})$ and filtered. Then a few drops of $1 \%$ ferric chloride were then added. Black or blue-green colouration indicates a positive result for the presence of tannins (Edeoga $\boldsymbol{e t}$ al. 2005)

\section{Test for saponins}

Crude extract $(50 \mathrm{mg}$ ) was diluted with distilled water and made up to $20 \mathrm{ml}$ The suspension shakes in a graduated cylinder for 15 minutes. A foam layer (2 $\mathrm{cm}$ ) indicates the presence of saponins (Yadav et al., 2017).

\section{Test for steroids}

Approximately $100 \mathrm{mg}$ of crude extract dissolved in $2 \mathrm{ml}$ of chloroform. Concentrated sulphuric acid added to form a lower layer. The reddish-brown colour at the interface indicated the presence of the steroid ring (Yadav $\boldsymbol{e t}$ al., 2017)

\section{Test for anthraquinone glycoside}

$5 \mathrm{ml}$ of extract was hydrolyzed with dilute sulphuric acid. After addition of $1 \mathrm{~m}$ of benzene and $1 \mathrm{ml}$ of $\mathrm{NH} 3$, the formation of Rose Pink colour indicates anthraquinone (Sawant and Godghate, 2013)

\section{Cytotoxicity assay}

To evaluate cell viability, MTT assay is a standard method (Shoemaker $\boldsymbol{e t}$ al. 2004; Peng et al., 2005). For the screening of cell viability-based test by MTT assay using tetrazolium salt (3-(4,5-dimethylthiazol-2-yl)-2,5diphenyltetrazolium bromide or MTT), the active cell viability was determined. The NIH/3T3 cell line was seeded into 96-well plates at $200 \mu$ l density of suspension contained approximately $1 \times 10^{4}$ cells/well in a volume. Following 24 $\mathrm{h}$ incubation and attachment, the cell lines were treated with different concentrations at 100, 200,300, 400 and $500 \mu \mathrm{g} / \mathrm{ml}$ of AESKL. The 96 well plates were incubated at $37^{\circ} \mathrm{C}$ in $5 \% \mathrm{CO}_{2}$ atmosphere for about $24 \mathrm{~h}$. After the incubation period, the media carefully aspirated without disrupting the MTT crystals at the bottom and $100 \mu \mathrm{l}$ of DMSO solution was added. Then the plate was gently shaken in a shaker to solubilize the formazan. The microplate reader used to measure the absorbance at $570 \mathrm{~nm}$ was noted using a spectrophotometer (Ayaz et al., 2016). Optical density values determined the concentration of AESKL capable of reducing viable cells by $50 \%$. The cytotoxicity test performed in duplicate, following formula used to calculate the $\%$ viability.

Cell viability $(\%)=($ Mean absorbance of treated group $/$ Mean absorbance of control) $\times 100$

\section{Experimental animals approved by the animal ethical committee}

In the present study, female Wistar Albino rats (150-250 gm), 8-12 weeks old, were used for the experiment. The rats were maintained in well-ventilated cages (temperature $25 \pm 2^{\circ} \mathrm{C}$ ) under natural light and dark cycles kept on pelletized animal feed with access to water ad libitum. The animals were treated according to Animal Ethics Committee guidelines in the Department of Pharmaceutical Technology of Jadavpur University, India (Registration number: 147/1999/CPCSEA).

\section{Acute oral toxicity design}

AESKL studied for their acute toxicity as per OECD guidelines-425 by following the study design of Saleem $\boldsymbol{e t}$ al., 2017. To the rat that is fed only water but not food overnight was subjected to single dosage level, $2000 \mathrm{mg} / \mathrm{kg}$ b.w of AESKL. The plant extract was given orally to one group that involves five female rats. Initially, one rat was dosed and strictly observed by withholding the food for $4 \mathrm{~h}$. Based on the results obtained from single rat, the remaining 4 rats were administered for dosing and observed for the first $4 \mathrm{~h}$ to $24 \mathrm{~h}$ and then for 14 days. Rats were observed for any signs of toxicity, incidence of mortality and b.w of all animals were recorded everyday to track their dietary intake and physical health in both groups of the regimens. Then, blood samples were collected by puncturing the cardiac intraperitoneally under anesthesia (ketamine $50 \mathrm{mg} / \mathrm{kg}$ and xylazine $5 \mathrm{mg} / \mathrm{kg}$ ). Vital organs were excised and preserved in $10 \%$ formalin for histological studies. Later $\mathrm{LD}_{50}$ was estimated.

\section{Collection of blood samples}

All rats were anesthetized soon after the oral acute toxicity study (14 days). The blood collected from rats in heparinised (ethylene diamine tetraacetate [EDTA]) tube is subjected to haematological evaluation. The blood in the non-heparinised tube (without EDTA) was allowed to coagulate and then centrifuged for serum separation. The separated serum is further used for biochemical analysis.

\section{Haematological analysis}

Automated analyser (KX-21 Hematology-analyzer) was utilized to evaluate the blood indices like haemoglobin $(\mathrm{Hb})$, red blood cells $(\mathrm{RBC})$, white blood cells (WBC), neutrophils (NP), lymphocytes (LC), and monocytes (MC).

\section{Biochemical analysis}

In clean dry tubes, blood samples were collected from animals and centrifuged a $3000 \mathrm{rpm}$ for $15 \mathrm{~min}$ by maintaining the temperature at $25^{\circ} \mathrm{C}$. The obtained blood serum was stored at $-20^{\circ} \mathrm{C}$. Serum for determination of total bilirubin, serum glutamic oxaloacetic transaminase (SGOT), serum glutamic pyruvic transaminase (SGPT), serum protein, creatinine, and urea were performed by Erbachem 5 semi-auto analyser.

\section{Histological study}

The vital organs (Liver and Kidney) isolated from sacrificed rats were immersed in $10 \%$ buffered formalin bottles and then processed for histological examination. The organs embedded in paraffin wax; serial section $(5-\mu \mathrm{m}$ thick) obtained by embedded tissue with a microtome. Haematoxylin and eosin $(\mathrm{H}$ and E) was used to stain the sections and deparaffinised with xylene followed by hydrating with alcohol (descending series). Nikon phase contrast microscope (YTV55 ECLIPSE) was used to observe the slides at 40X and multiple fields were analysed (Syahmi et al., 2010).

\section{Statistical analysis}

Data expressed as mean \pm SEM and one way analysis of Dunnett T3 test (ANOVA) used to analyze the significance of AESKL by comparing with NC with the help of SPSS software, version 20; values considered statistically significant when $\mathrm{p}<0.05$. 


\section{RESULTS}

\section{Phytochemical screening}

The extract appeared in brown and pleasant smell. The phenolic compounds, terpenoids, tannins, saponins and steroids were present in the crude extract. The preliminary phytochemical results of the AESKL are shown in Table 1.

Table 1 Phytochemical properties of AESKL

\begin{tabular}{lc}
\hline Phytochemicals test & AESKL \\
\hline Alkaloids & -ve \\
Phenolic compounds & $+\mathrm{ve}$ \\
Flavonoids & $-\mathrm{ve}$ \\
Terpenoids & $+\mathrm{ve}$ \\
Tannins & $+\mathrm{ve}$ \\
Saponins & $+\mathrm{ve}$ \\
Steroids & $+\mathrm{ve}$ \\
Anthraquinone glycoside & $-\mathrm{ve}$ \\
\hline Legend: +ve - presence, -ve - absence
\end{tabular}

\section{Cytotoxicity by MTT assay using NIH/3T3 cell line}

The MTT assay results, expressed as $\mathrm{IC}_{50}$ value shown in Table 2 . The dosedependent NIH/3T3 cell line cell viability decreased after $24 \mathrm{~h}$ in the extracttreated. $500 \mu \mathrm{g} / \mathrm{ml}$ concentration showed more than $50 \%$ decrease in the cell viability. AESKL showed the $\mathrm{IC}_{50}$ value of $491.56 \mu \mathrm{g} / \mathrm{ml}$.
Table 2 Cytotoxicity study of AESKL on NIH/3T3 cell line NIH/3T3 Vs AESKL

\begin{tabular}{lcc}
\hline Concentration $(\boldsymbol{\mu g} / \mathbf{m l})$ & Mean \pm standard error & \% Cell Viability \\
\hline 100 & $0.2805 \pm 0.011$ & 63.99 \\
200 & $0.1795 \pm 0.012$ & 65.41 \\
300 & $0.1835 \pm 0.004$ & 57.21 \\
400 & $0.1605 \pm 0.016$ & 56.14 \\
500 & $0.1575 \pm 0.015$ & 47.59 \\
Untreated & $0.1335 \pm 0.015$ & 100 \\
IC $_{\mathbf{5 0}}=\mathbf{4 9 1 . 5 6} \boldsymbol{\mu g} / \mathbf{m l}$ & & $\mathbf{R}^{\mathbf{2}=\mathbf{0 . 8 7 0}}$ \\
\hline
\end{tabular}

Legend: $\mathrm{IC}_{50}-50 \%$ Inhibitory concentration

\section{Acute oral toxicity evaluation}

Acute toxicity in rats was studied by giving single dose of $2000 \mathrm{mg} / \mathrm{kg} \mathrm{b} . \mathrm{w}$ orally. During the study period, the b.w in both the NC and AESKL $(2000 \mathrm{mg} / \mathrm{kg}$ b.w) groups were increased (Table 3). The behavior pattern of the NC and AESKL groups effect was noted. After $24 \mathrm{~h}$, no mortality or any other symptoms were observed in treated rats, however one particular rat slept for about 20 minutes after dosing. During the experimental time of 14 days, no detectable evidence of toxicity was found (Table 4).

Table 3 Effect of AESKL on b.w of rats in acute toxicity study

\begin{tabular}{llll}
\hline Groups & $\mathbf{1}^{\text {st }}$ Day & $\mathbf{7}^{\text {th }}$ Day & $\mathbf{1 4}^{\text {th }}$ Day \\
\hline NC & $170.52 \pm 0.65$ & $172.58 \pm 1.49$ & $177.05 \pm 0.85$ \\
AESKL $(2000 \mathrm{mg} / \mathrm{kg}$ b.w & $170.28 \pm 0.86$ & $171.68 \pm 0.75$ & $177.26 \pm 0.87$ \\
\hline Data expressed mean \pm SEM $(\mathrm{n}=5)$ (Anova/Dunnett T3 test); no significant variations
\end{tabular}

between the groups. Legend: $\mathrm{NC}-$ normal control

Table 4 Observation for the AESKL at $2000 \mathrm{mg} / \mathrm{kg}$ b.w of rats

\begin{tabular}{|c|c|c|c|c|c|c|c|c|c|c|c|c|}
\hline \multirow{2}{*}{ Observation } & \multicolumn{2}{|c|}{30 Min. } & \multicolumn{2}{|c|}{$4 \mathrm{Hrs}$} & \multicolumn{2}{|c|}{24 Hrs. } & \multicolumn{2}{|c|}{48 Hrs. } & \multicolumn{2}{|c|}{1 Week } & \multicolumn{2}{|c|}{2 Week } \\
\hline & $\mathrm{C}$ & $\mathrm{E}$ & $\mathrm{C}$ & $\mathrm{E}$ & $\mathrm{C}$ & $\mathrm{E}$ & $\mathrm{C}$ & $\mathrm{E}$ & $\mathrm{C}$ & $\mathrm{E}$ & $\mathrm{C}$ & $\mathrm{E}$ \\
\hline Skin and Fur & $\mathrm{N}$ & $\mathrm{N}$ & $\mathrm{N}$ & $\mathrm{N}$ & $\mathrm{N}$ & $\mathrm{N}$ & $\mathrm{N}$ & $\mathrm{N}$ & $\mathrm{N}$ & $\mathrm{N}$ & $\mathrm{N}$ & $\mathrm{N}$ \\
\hline Eyes & $\mathrm{N}$ & $\mathrm{N}$ & $\mathrm{N}$ & $\mathrm{N}$ & $\mathrm{N}$ & $\mathrm{N}$ & $\mathrm{N}$ & $\mathrm{N}$ & $\mathrm{N}$ & $\mathrm{N}$ & $\mathrm{N}$ & $\mathrm{N}$ \\
\hline Mucous Membrane & $\mathrm{N}$ & $\mathrm{N}$ & $\mathrm{N}$ & $\mathrm{N}$ & $\mathrm{N}$ & $\mathrm{N}$ & $\mathrm{N}$ & $\mathrm{N}$ & $\mathrm{N}$ & $\mathrm{N}$ & $\mathrm{N}$ & $\mathrm{N}$ \\
\hline Salivation & $\mathrm{N}$ & $\mathrm{N}$ & $\mathrm{N}$ & $\mathrm{N}$ & $\mathrm{N}$ & $\mathrm{N}$ & $\mathrm{N}$ & $\mathrm{N}$ & $\mathrm{N}$ & $\mathrm{N}$ & $\mathrm{N}$ & $\mathrm{N}$ \\
\hline Lethargy & Nil & Nil & Nil & Nil & Nil & Nil & Nil & Nil & Nil & Nil & Nil & Nil \\
\hline Sleep & $\mathrm{N}$ & $\uparrow$ & $\mathrm{N}$ & $\mathrm{N}$ & $\mathrm{N}$ & $\mathrm{N}$ & $\mathrm{N}$ & $\mathrm{N}$ & $\mathrm{N}$ & $\mathrm{N}$ & $\mathrm{N}$ & $\mathrm{N}$ \\
\hline Coma & Nil & Nil & Nil & Nil & Nil & Nil & Nil & Nil & Nil & Nil & Nil & Nil \\
\hline Convulsion & Nil & Nil & Nil & Nil & Nil & Nil & Nil & Nil & Nil & Nil & Nil & Nil \\
\hline Tremors & Nil & Nil & Nil & Nil & Nil & Nil & Nil & Nil & Nil & Nil & Nil & Nil \\
\hline Diarrhea & Nil & Nil & Nil & Nil & Nil & Nil & Nil & Nil & Nil & Nil & Nil & Nil \\
\hline Morbidity & Nil & Nil & Nil & Nil & Nil & Nil & Nil & Nil & Nil & Nil & Nil & Nil \\
\hline Mortality & Nil & Nil & Nil & Nil & Nil & Nil & Nil & Nil & Nil & Nil & Nil & Nil \\
\hline
\end{tabular}

\section{Organ weights of rats in acute toxicity study}

Isolated organs found to be free of any lesion and no significant changes occur in the respective organ weight (Table 5). The importance of the organ is that it plays as an essential indicator of pathological and physiological status of animals (Raina et al., 2015)

$\underline{\text { Table } 5 \text { Effect of AESKL on organ weights of rats in acute toxicity study }}$

\begin{tabular}{lccccc}
\hline \multirow{2}{*}{ Groups } & \multicolumn{4}{c}{ Organs weight (gram) } \\
\cline { 2 - 5 } & Lungs & Heart & Liver & Pancreas & Kidneys \\
\hline NC & $1.41 \pm 0.01$ & $0.60 \pm 0.01$ & $5.39 \pm 0.01$ & $0.49 \pm 0.01$ & $0.52 \pm 0.02$ \\
AESKL $(2000 \mathrm{mg} / \mathrm{kg} \mathrm{b.w)}$ & $1.35 \pm 0.01$ & $0.57 \pm 0.02$ & $5.36 \pm 0.03$ & $0.42 \pm 0.01$ & $0.50 \pm 0.02$ \\
\hline Data expressed as mean \pm SEM $(\mathrm{n}=5)$ (Anova/Dunnett T3 test); no significant variations between the groups. Legend: NC - normal control
\end{tabular}

\section{Effects of AESKL on haematological parameters}

The results of haematological parameters carried out in both groups by estimating the blood count is shown in Table 6. There was a significant change in total RBC $(\mathrm{p}<0.05)$ and lymphocyte $(\mathrm{p}<0.05)$ count, when treated group compared with the NC group. The other parameters of $\mathrm{Hb}, \mathrm{WBC}, \mathrm{NP}$, and MC did not show any significant differences between the groups.

Table 1 Effect of AESKL on hematological parameters of rats in acute toxicity study

\begin{tabular}{lcccccc}
\hline \multirow{2}{*}{ Groups } & \multicolumn{4}{c}{ Parameters } \\
\cline { 2 - 7 } & $\mathbf{H b}(\mathbf{g} / \mathbf{d L})$ & $\begin{array}{c}\text { Total } \mathbf{R B C} \\
(\mathbf{1 0} / \boldsymbol{\mu L})\end{array}$ & $\mathbf{W B C}(\mathbf{1 0} / \boldsymbol{\mu L})$ & $\mathbf{N P}(\boldsymbol{\%})$ & $\mathbf{L C}(\boldsymbol{\%})$ & $\mathbf{M C}(\boldsymbol{\%})$ \\
\hline NC & $13.14 \pm 0.29$ & $6.86 \pm 0.02$ & $7.16 \pm 0.18$ & $18.28 \pm 0.01$ & $67.01 \pm 0.74$ & $2.32 \pm 0.11$ \\
AESKL(2000 mg/kg b.w) & $13.04 \pm 0.23$ & $5.93 \pm 0.03 *$ & $7.22 \pm 0.17$ & $20.36 \pm 0.38$ & $57.50 \pm 0.77 *$ & $2.32 \pm 0.06$ \\
\hline
\end{tabular}

Data expressed as mean \pm SEM $(n=5)$ (Anova/Dunnett T3 test); $* \mathrm{P}<0.05$ indicates significant variations between the groups.

Legend: NC - normal control, $\mathrm{Hb}$ - haemoglobin, RBC - red blood cells, WBC - white blood cells, NP - neutrophils, LC - lymphocytes, and MC - monocytes. 
Effect of AESKL on biochemical parameters in acute toxicity study. serum protein, creatinine, urea, SGOT, and SGPT levels as compared with NC Oral administration of AESKL showed no significant variations in total bilirubin, group (Table 7).

Table 7 Effects of AESKL on biochemical estimation of rats in acute toxicity study

\begin{tabular}{lcccccc}
\hline \multirow{2}{*}{ Groups } & \multicolumn{5}{c}{ Parameters } \\
\cline { 2 - 7 } & $\begin{array}{c}\text { Total bilirubin } \\
(\mathbf{m g} / \mathbf{d L})\end{array}$ & $\begin{array}{c}\text { Serum Protein } \\
(\mathbf{g} / \mathbf{d L})\end{array}$ & $\begin{array}{c}\text { Creatinine } \\
(\mathbf{m g} / \mathbf{d L})\end{array}$ & $\begin{array}{c}\text { Urea } \\
(\mathbf{m g} / \mathbf{d L})\end{array}$ & $\begin{array}{c}\text { SGOT } \\
(\text { IU/L) }\end{array}$ & $\begin{array}{c}\text { SGPT } \\
(\mathbf{I U} / \mathbf{L})\end{array}$ \\
\hline NC & $0.45 \pm 0.02$ & $8.18 \pm 0.02$ & $0.34 \pm 0.01$ & $56.13 \pm 3.98$ & $411.80 \pm 2.69$ & $42.89 \pm 6.00$ \\
AESKL (2000 mg/kg b.w) & $0.38 \pm 0.01$ & $8.14 \pm 0.19$ & $0.36 \pm 0.01$ & $60.20 \pm 4.83$ & $398.80 \pm 2.63$ & $37.74 \pm 7.05$ \\
\hline
\end{tabular}

Data expressed as mean \pm SEM $(n=5)$ (Anova/Dunnett T3 test); no significant variations between the groups.

Legend: NC - normal control, SGOT - serum glutamic oxaloacetic transaminase, SGPT - serum glutamic pyruvic transaminase

\section{Histological study}

In histological study, organ sections of the liver in $\mathrm{NC}$ rats showed normal appearance of central vein and nucleus (Figure 3A) and no apparent changes were observed when compared with $\mathrm{NC}$ group at the cellular level in AESKL group (Figure 3B). In the light microscope, the liver of NC and AESKL (2000 $\mathrm{mg} / \mathrm{kg} \mathrm{b.w)} \mathrm{group} \mathrm{revealed} \mathrm{characteristic} \mathrm{of} \mathrm{normal} \mathrm{structure.} \mathrm{Nucleus} \mathrm{(N)}$ appeared spherical and contained RBC (Red Blood Cells). In the kidney, glomerulus (G) and tubules ( $\mathrm{T}$ ) showing the same structure in both groups (Figure 4A and 4B).
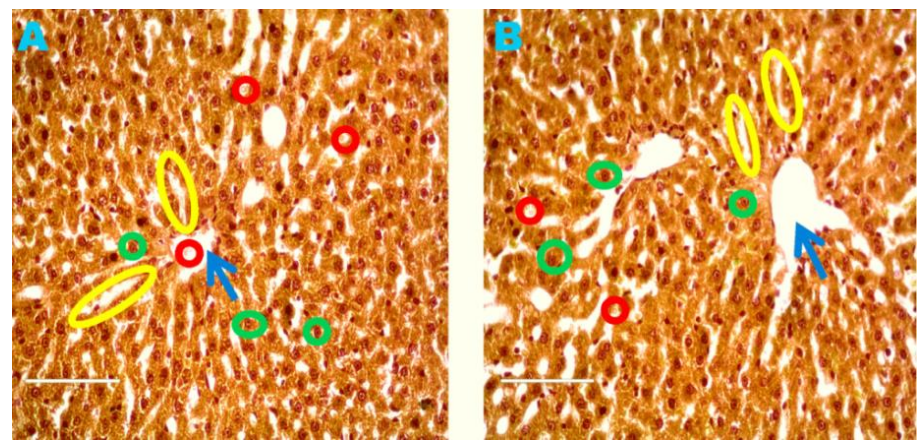

Figure 3 Photomicrograph of liver sections (H \& E). (A) $N C$ (40x) and (B) AESKL treated $(40 \mathrm{x})$. The blue arrow indicates the central vein; the green circle indicates $\mathrm{N}$, red circle indicates RBC, and the yellow circle indicates blood sinusoids.

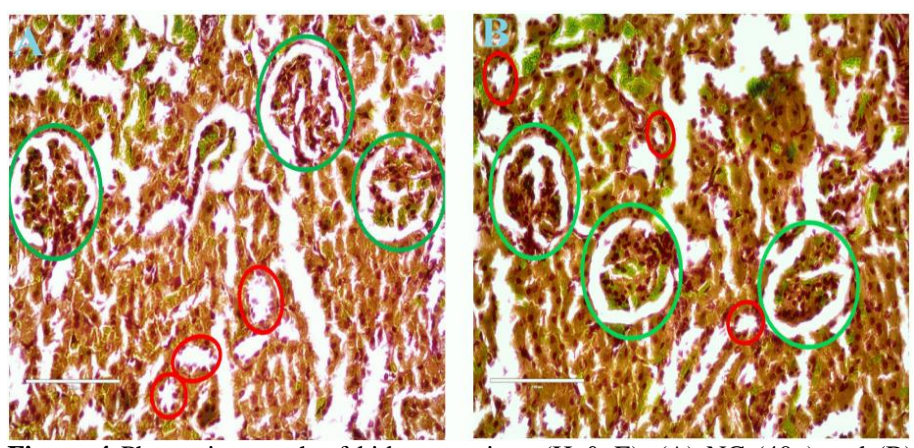

Figure 4 Photomicrograph of kidney sections (H \& E). (A) NC (40x) and (B) AESKL (40x). The green circle indicates $\mathrm{G}$, red circle indicates $\mathrm{T}$.

\section{DISCUSSION}

Globally, herbal medicines are getting significant attention and are accepted widely as a source of drugs, especially in low and middle- income countries (Vaghasiya et al., 2011). Toxicity study is mandatory for the development of pharmaceutical and pharmacological product from any medicinal plant as per the standard guidelines (Mohs and Greiget 2017). In the current study, a rare and unexplored species of Syzygium was chosen to explore its toxicological properties. The aqueous extract of $S$. kanarense was found to be non-toxic. The study also reported various bioactive compounds present in the extract (phenolics, tannins, terpenoids, saponins and steroids) which is highlighted in Table 1. Cytotoxicity study of extract on mouse embryonic fibroblast cell line (NIH/3T3) was determined through MTT assay and cytotoxic effects are expressed in $\mathrm{IC}_{50}$ value (Table 2.) The results of MTT assay indicated that AESKL on NIH/3T3 cell line showed more than $50 \%$ toxic effects in the concentration of $500 \mu \mathrm{g} / \mathrm{ml}$.

Evaluation of acute toxicity in plant extracts helps in identifying the toxicologica role and plays an essential part in designing the drugs. The present study of acute toxicity in single dose treatment at $2000 \mathrm{mg} / \mathrm{kg}$ concentration of AESKL showed no mortality. Toxic effects of chemicals assist in identifying the variations of body weights (Abubakar et al., 2019). In this research, oral administration of
AESKL did not reduce the body weights of the rats implying that it did not exert any deteriorative effect on their growth (Table 3). There were no significant variations detected in clinical signs, change in the skin, eye colour change, general physique, diarrhoea and coma in female rats for 14 days (Table 4). The changes in b.w and internal organ weight indicate the first sign of toxicity when exposed to toxic substances (Sireeratawong et al., 2008). Water and healthy food provided to Wistar albino rats influenced in increasing b.w along with their activeness throughout the study period and based on the above results, it is clear that acute toxicity studies on AESKL are practically non-toxic in rats. Hematopoiesis system is the formation of cellular blood components, and it is essential for physiological and pathological status (Almanca et al., 2011; Mukinda et al., 2010). In this trail, oral administration of single dose AESKL did not cause significant changes on haematological parameters when compared the treated group with the NC group, thus suggesting that the extract is safe and non-toxic to the blood system.

The liver and kidney are vital organs that play a role in detoxification (Harizal et al., 2010). An increase in the SGOT, SGPT, ALP and total bilirubin levels in blood of the experimental animals are specific markers for liver damage (Thapa et al., 2007; Chavda et al., 2010). Administration of AESKL showed no significant variations in SGOT, SGPT, serum protein and total bilirubin level was observed in the treated groups when compared with NC groups. This indicates that the functions of the liver is not affected by the extract after 14 days of treatment. Thus, animals treated with AESKL found to be non-hepatotoxic Creatinine and urea are regarded as essential markers of kidney function to diagnose (Sood et al., 2015). In the present study, no significant changes in creatinine and urea in treated groups were observed after giving AESKL, when compared with NC groups. This suggests that AESKL found to be safe and nontoxic to the kidney. The above mentioned biochemical investigation was in correlation with the histological studies. The section of liver-kidney also confirmed that the AESKL treated rats up to $2000 \mathrm{mg} / \mathrm{kg}$ b.w showed no changes compared with NC observed under the light microscope.

\section{CONCLUSION}

Aqueous leaves extract of rare and unexplored $S$. kanarense was selected for phytochemical investigation and its toxicological studies, which resulted in many secondary metabolites like phenolics, terpenoids, tannins, saponins, steroids, volatile oil, and glycosides. Cytotoxicity studies by MTT assay on NIH/3T3 cell line revealed $\mathrm{IC}_{50}$ value of $491.56 \mu \mathrm{g} / \mathrm{ml}$ range. The oral dose upto $2000 \mathrm{mg} / \mathrm{kg}$ of AESKL for 14 days showed no treatment-related morbidity or mortality in the rats. In addition, hematological, biochemical serum analysis and histological study at the cellular level also did not show any marked effect. Based on this study, we can conclude that AESKL ( $2000 \mathrm{mg} / \mathrm{kg}$ ) was found to be non-toxic and can be used for further evaluation of pharmacological activities. A focus of the study in this direction certainly would bring aware in availing the health benefits of natural plant extracts alternative to synthesized chemical toxicity. Further studies are under process on anti-diabetic research.

Acknowledgements: First author would like to thank Mangalore University, Mangalagangothri, for providing fellowship to carry out the research.

\section{REFERENCES}

Abubakar, A., Nazifi, A. B., Hassan, F. I., Duke, K. A., Edoh, T. D. (2019). Safety assessment of Chlorophytum alismifolium tuber extract (Liliaceae): Acute and sub-acute toxicity studies in Wistar rats. Journal of Acute Diseas, 8(1), 21. http://dx.doi.org/10.4103/2221-6189.250374.

Almança, C. C. J., Saldanha, S. V., Sousa, D. R., Trivilin, L. O., Nunes, L. C., Porfírio, L. C., \& Marinho, B. G. (2011). Toxicological evaluation of acute and sub-chronic ingestion of hydroalcoholic extract of Solanum cernuum Vell. in mice. Journal of Ethnopharmacology, 138(2), 508-512. http://dx.doi.org/10.1016/j.jep.2011.09.045

Ayaz, M., Junaid, M., Ullah, F., Sadiq, A., Subhan, F., Khan, M. A., ... Ahmad, S. (2016). Molecularly Characterized Solvent Extracts and Saponins from Polygonum hydropiper L. Show High Anti-Angiogenic, Anti-Tumor, Brine Shrimp, and Fibroblast NIH/3T3 Cell Line Cytotoxicity. Frontiers in Pharmacology, 7. http://dx.doi.org/10.3389/fphar.2016.00074 
Banu, K. S., \& Cathrine, L. (2015). General techniques involved in phytochemical analysis. International Journal of Advanced Research in Chemical Science, 2(4), 25-32.

Chavda, R., Vadalia, K. R., \& Gokani, R. (2010). Hepatoprotective and Antioxidant Activity of Root Bark of Calotropis procera $\mathrm{R} . \mathrm{Br}$ (Asclepediaceae). International Journal of Pharmacology, 6(6), 937-943. http://dx.doi.org/10.3923/ijp.2010.937.943

Chew, K. H., Ling, A. P. K., Chye, S. M., \& Koh, R. Y. (2017). An Overview of Pharmacological Activities of Syzygium Species. Cancer, 33, 35.

Edeoga, H. O., Okwu, D. E., \& Mbaebie, B. O. (2005). Phytochemical constituents of some Nigerian medicinal plants. African Journal of Biotechnology, 4(7), 685-688. http://dx.doi.org/10.5897/ajb2005.000-3127

Harizal, S. N., Mansor, S. M., Hasnan, J., Tharakan, J. K. J., \& Abdullah, J. (2010). Acute toxicity study of the standardized methanolic extract of Mitragyna speciosa Korth in Rodent. Journal of Ethnopharmacology, 131(2), 404-409. http://dx.doi.org/10.1016/j.jep.2010.07.013

Joshi, R. K., Shenoy, H. S., \& Marati, R. (2017). Chemical Composition of the Essential oil of Syzygium kanarense: An Endemic and Rediscovered Species from the Western Ghats, India. Natural Product Communications, 12(12), 1934578X1701201. http://dx.doi.org/10.1177/1934578x1701201232

Koehn, F. E., \& Carter, G. T. (2005). The evolving role of natural products in drug discovery. Nature Reviews Drug Discovery, 4(3), 206-220. http://dx.doi.org/10.1038/nrd1657

Lietava, J. (1992). Medicinal plants in a Middle Paleolithic grave Shanidar IV? Journal of Ethnopharmacology, 35(3), 263-266. http://dx.doi.org/10.1016/0378 $\underline{8741(92) 90023-\mathrm{k}}$

Mohanraj, K., Karthikeyan, B. S., Vivek-Ananth, R. P., Chand, R. P. B., Aparna S. R., Mangalapandi, P., \& Samal, A. (2018). IMPPAT: A curated database of Indian Medicinal Plants, Phytochemistry and Therapeutics. Scientific Reports, 8(1). http://dx.doi.org/10.1038/s41598-018-22631-z

Mohs, R. C., \& Greig, N. H. (2017). Drug discovery and development: Role of basic biological research. Alzheimer's \& Dementia: Translational Research \&

Clinical

Interventions, 3(4),

651-657.

http://dx.doi.org/10.1016/j.trci.2017.10.005

Mukinda, J. T., \& Eagles, P. F. K. (2010). Acute and sub-chronic oral toxicity profiles of the aqueous extract of Polygala fruticosa in female mice and rats. Journal of Ethnopharmacology, 128(1), 236-240. http://dx.doi.org/10.1016/j.jep.2010.01.022

Nigam, V., \& Nigam, R. (2012). Distribution and Medicinal Properties of Syzygium species. Current Research in Pharmaceutical Sciences, 73-80.

Patwardhan, B., Vaidya, A. D., \& Chorghade, M. (2004). Ayurveda and natural products drug discovery. Current science, 789-799.

Peng, L., Wang, B., \& Ren, P. (2005). Reduction of MTT by flavonoids in the absence of cells. Colloids and Surfaces B: Biointerfaces, 45(2), 108-111. http://dx.doi.org/10.1016/j.colsurfb.2005.07.014

Raina, P., Chandrasekaran, C. V., Deepak, M., Agarwal, A., \& Ruchika, K. G. (2015). Evaluation of subacute toxicity of methanolic/aqueous preparation of aerial parts of $O$. sanctum in Wistar rats: Clinical, haematological, biochemical and histopathological studies. Journal of Ethnopharmacology, 175, 509-517. http://dx.doi.org/10.1016/j.jep.2015.10.015

Saad, B., Azaizeh, H., Abu-Hijleh, G., \& Said, O. (2006). Safety of Traditional Arab Herbal Medicine. Evidence-Based Complementary and Alternative Medicine, 3(4), 433-439. http://dx.doi.org/10.1093/ecam/nel058

Saleem, U., Amin, S., Ahmad, B., Azeem, H., Anwar, F., \& Mary, S. (2017). Acute oral toxicity evaluation of aqueous ethanolic extract of Saccharum munja Roxb. roots in albino mice as per OECD 425 TG. Toxicology Reports, 4, 580 585. http://dx.doi.org/10.1016/j.toxrep.2017.10.005

Sawant, R. S., \& Godghate, A. G. (2013). Qualitative phytochemical screening of rhizomes of Curcuma longa Linn. International Journal of Science, Environment and Technology, 2(4), 634-641.

Shenoy, H. S., Krishnakumar, G., \& Marati, R. (2015). Rediscovery of Syzygium kanarense (Talbot) Raizada (Myrtaceae) - an endemic species of the Western Ghats, India. Journal of Threatened Taxa, 7(1), 6833-6835. http://dx.doi.org/10.11609/JoTT.o3298.6833-5

Shoemaker, M., Cohen, I., \& Campbell, M. (2004). Reduction of MTT by aqueous herbal extracts in the absence of cells. Journal of Ethnopharmacology, 93(2-3), 381-384. https://doi.org/10.1016/j.jep.2004.04.011

Ghosh, S., \& Rangan, L. (2013). Alpinia: the gold mine of future therapeutics. 3 Biotech, 3(3), 173-185. https://doi.org/10.1007/s13205-012-0089-x

Sireeratawong, S., Lertprasertsuke, N., Srisawat, U., Thuppia, A., Ngamjariyawat, A., Suwanlikhid, N., \& Jaijoy, K. (2008). Acute and subchronic toxicity study of the water extract from Tiliacora triandra (Colebr.) Diels in rats. Songklanakarin Journal of Science \& Technology, 30(5).

Sood, M. M., Saeed, M., Lim, V., Cordova, F., Komenda, P., Malik, A., \& Zieroth, S. (2015). The Urea-to-Creatinine Ratio Is Predictive of Worsening Kidney Function in Ambulatory Heart Failure Patients. Journal of Cardiac Failure, 21(5), 412-418. http://dx.doi.org/10.1016/j.cardfail.2015.02.003

Syahmi, A. R. M., Vijayarathna, S., Sasidharan, S., Latha, L. Y., Kwan, Y. P., Lau, Y. L., \& Chen, Y. (2010). Acute Oral Toxicity and Brine Shrimp Lethality of Elaeis guineensis Jacq., (Oil Palm Leaf) Methanol Extract. Molecules, 15(11), 8111-8121. http://dx.doi.org/10.3390/molecules 15118111

Thapa, B. R., \& Walia, A. (2007). Liver function tests and their interpretation. The Indian Journal of Pediatrics, 74(7), 663-671. http://dx.doi.org/10.1007/s12098-007-0118-7

Vaghasiya, Y. K., Shukla, V. J., \& Chanda, S. V. (2011). Acute Oral Toxicity Study of Pluchea arguta Boiss Extract in Mice. Journal of Pharmacology and Toxicology, 6(2), 113-123. http://dx.doi.org/10.3923/jpt.2011.113.123

Yadav, R., Khare, R. K., \& Singhal, A. (2017). Qualitative Phytochemical Screening of Some Selected Medicinal Plants of Shivpuri District (M.P.). International Journal of Life-Sciences Scientific Research, 3(1). http://dx.doi.org/10.21276/ijlssr.2017.3.1.16

Yuan, H., Ma, Q., Ye, L., \& Piao, G. (2016). The Traditional Medicine and Modern Medicine from Natural Products. Molecules, 21(5), 559. http://dx.doi.org/10.3390/molecules21050559 